\title{
A Study on Measurements of Different Dimensions of Maxillary Sinus by Computed Tomography in Adult Nepalese Population
}

\author{
Khanal UP, Adhikari A, Humagai MP
}

Department of Radiology and Imaging, Tribhuvan University Teaching Hospital, Kathmandu, Nepal.

Received: November 20, 2018

Accepted: November 30, 2018

Published: December 30, 2018

Cite this paper:

KhanalUP,AdhikariA,Humagai MP.Astudy onmeasurements of different dimensions of maxillary sinus by Computed Tomography in adult Nepalese population. Nepalese Journal of Radiology 2018;8(12):8-12. https://doi.org/10.3126/njr.v8i2.22974

\begin{abstract}
Introduction: Measurement of different dimensions of maxillary sinus and anterior wall thickness of maxillary sinus by Computed Tomography in normal Nepalese population

Methods: Dimensions of 90 patients were measured in CT PNS using Syngovia Software. AP diameter, width and anterior wall thickness were measured in axial images and height was measured in coronal images.

Results: The mean volume of maxillary sinuses in study of male population on left and right side were $17.09 \mathrm{~cm}^{3} \pm 3.89,17.19 \mathrm{~cm}^{3} \pm 4$ respectively whereas in female were $15.64 \mathrm{~cm}^{3} \pm 3.5$ and $15.21 \mathrm{~cm}^{3} \pm 3.2$ respectively as shown in Table 1 . This shows the volume of male was significantly larger than female with P- Value $=0.012(<0.05)$. Similarly, the thickness of Anterior Wall (AW) of maxillary sinus was also measured in this study and the mean value of left and right side in male were $0.16 \mathrm{~cm} \pm 0.04$ and $0.15 \mathrm{~cm} \pm 0.03$ respectively and in female were $0.12 \mathrm{~cm} \pm 0.04$ and $0.14 \mathrm{~cm} \pm 0.02$ respectively.

Conclusion: This study showed that CT is a reliable method for the measurement of different dimensions of the maxillary sinus. The result showed greater mean value of volume in male than female with significant differences. So this study concluded that the measurement of volume of maxillary sinus can help in the identification of gender which can be very useful for forensic sciences.
\end{abstract}

Key words: Humans; Maxillary Sinus; Tomography, X-Ray Computed

\section{INTRODUCTION}

Correspondence to: Dr. Umesh Prasad Khanal

Assistant Professor

Department of Radiology and Imaging

Institute of Medicine

Tribhuvan University Teaching Hospital

Kathmandu, Nepal

E-mail: upkhanal2007@gmail.com
The paranasal sinuses are complex anatomical structures with a significant inter-individual variation. The use of computed tomography (CT) instead of plain radiography in the work-up of paranasal sinus pathology was recommended in the beginning of the 1990 's. ${ }^{1}$ 
Individual identification is a subtle concept and often one of the most important priorities in mass disasters, road accidents, air crashes, fires, and even in the investigation of criminal cases. Matching specific features detected on the cadaver with data recorded during the life of an individual is an important aspect in forensics, and can be performed by fingerprint analysis, deoxyribonucleic acid matching, anthropological methods, radiological methods and other techniques which can facilitate age and sex identification. Sinus radiography is one such method that has been used for determination of the sex of an individual. Hence, an attempt is being made to use the different dimensions of the maxillary sinus in the determination of sex using coronal and axial sections of plain computed tomography (CT) scan. ${ }^{2}$

Maxillary sinus is the largest of paranasal sinuses located in the body of maxilla. There are various shapes of maxillary sinus, that is; triangular, leaf, scapular, and renal shaped. ${ }^{3}$ It varies greatly in size, shape, and position not only in different individuals but also in different sides of the same individuals. Hence, maxillary sinus can be used for gender determination. ${ }^{2}$

This study helps to find out the normal dimensions of maxillary sinus in different age groups and sex groups, and hence help to determine upper limit of normal dimension of maxillary sinus. Measuring the dimensions and volume of maxillary sinus helps for gender determination in forensic sciences.

CT scanning is a non-invasive diagnostic imaging procedure that uses a combination of $\mathrm{X}$-rays and computer technology to produce horizontal, or axial, images (often called slices) of the body. CT scans are more detailed than conventional X-rays. In conventional $\mathrm{X}$-rays, a beam of X-rays is aimed at the body part being studied. A detector behind the body part captures the variations of the energy beam after it passes through skin, bone, muscle, and other tissue. While much information can be obtained from a conventional X-ray, detail information of internal organs and other structures is not available. In CT, the $\mathrm{X}$-ray beam moves in a circular pattern around the body. This allows many different views of the same organ or structure. The $\mathrm{X}$-ray information is sent to a computer that interprets the X-ray data and displays it in a two- dimensional (2D) form on a monitor. CT scans may be done with or without contrast media. Patient should be in supine position with Head first with arms beside the trunk for CT scan of PNS. Topogram is taken in Lateral position 2-3 cm anterior to the tip of nose for coronal, level of the vertex for axial, including from the level of the hard palate to the upper limit of frontal sinus.

\section{METHODS}

\section{Study design}

This was a prospective study carried out at Department of Radiology and Imaging, Tribhuvan University Teaching Hospital, Kathmandu, Nepal during the period from June 2017 to September 2017. Sample was taken through random sampling method.

\section{Inclusion Criteria}

A total of ninety nine patients were included in this study, (above 18 years) referred for CT PNS but without pathological findings. Patients of both genders were selected.

\section{Exclusion criteria}

Patients with history of any sinus pathology or trauma, facial asymmetry or septal deviation, or who has undergone surgical procedures were excluded.

\section{Materials used \\ Method of Measurement}

In this study, CT scan was performed on Siemens Somatom Definition $\mathrm{AS}^{+}$and dimensions of maxillary sinus were measured in axial and coronal sections (Figure 1). Data were transferred to the workstation Syngo.via Software and obtained images were reviewed by radiologists. 
$\underline{\text { In axial slices }}$

1. The width at the middle of the maxillary sinus

2. Maximal depth (anteroposterior) diameter

3. The thickness of the bony anterior wall (at canine fossa)

\section{$\underline{\text { In coronal slices }}$}

1. Maximal height of the maxillary sinus. After measuring all three dimensions, volume of the maxillary sinus was calculated using the following formula:

Maxillary sinus volume $=$ Width $\mathrm{x}$ anteroposterior $\mathrm{x}$ craniocaudal diameter $\mathrm{x}$ $0.5 .^{1}$
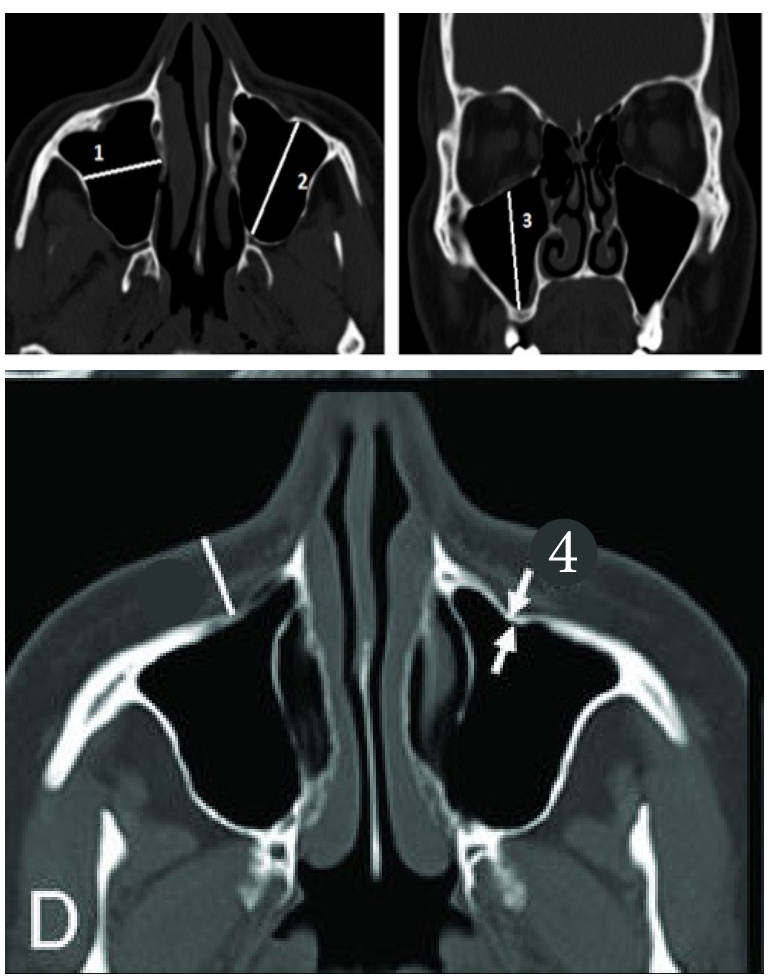

Figure 1: Measurements; 1: Width, 2: AP diameter, 3: Height, 4: AWT

\section{Data analysis}

Statistical analysis was carried out with the help of SPSS version 20 and Microsoft Excel.

\section{RESULTS}

A total of 90 patients were enrolled in this study. Among 90 samples, 46 were male and 44 were female consisting of $52 \%$ and $48 \%$ respectively which is shown in Figure 2.
Descriptive statistics of different measured variables were presented in Table 1. P-value of volume of male and female in different sides was calculated using one way ANOVA which was presented in Table 2. And by comparing the mean volume of both sides between male and female, a significant difference between male and female was shown with p-value 0.012 at $95 \%$ CI.

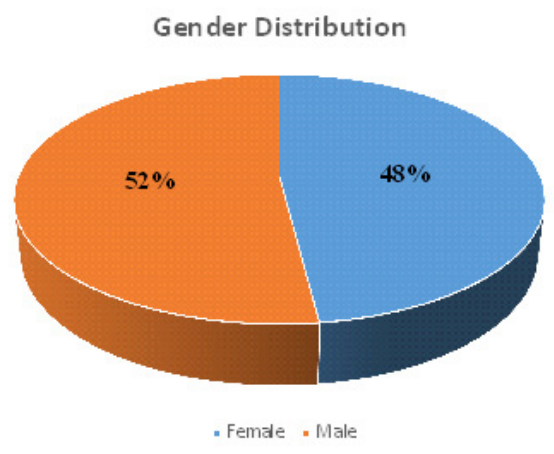

Figure 2: Gender Distribution of Population Mean Volume Distribution

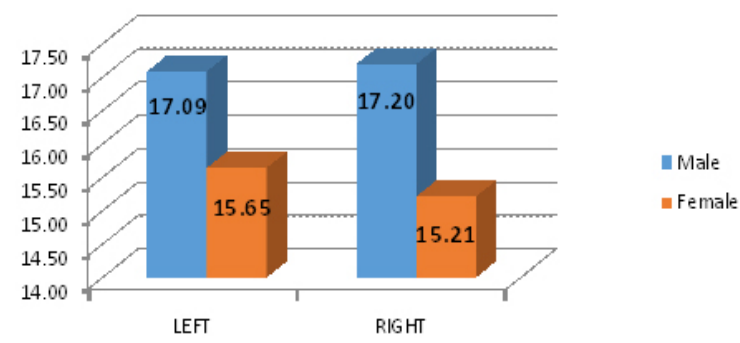

Figure 3: Distribution of Mean Volume of both left and right side in Male and Female

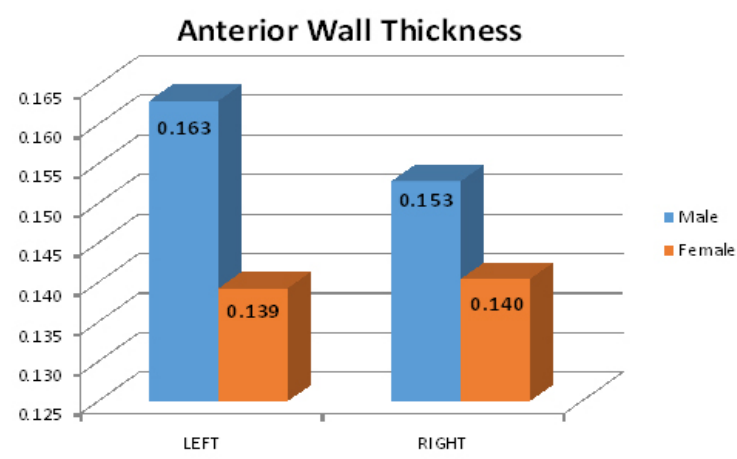

Figure 4: Distribution of Mean value of AWT of both left and right side in Male and Female 
Table 1: Male, Female distribution of Mean Value, SD, Median and Range

\begin{tabular}{|c|c|c|c|c|c|c|c|c|c|c|}
\hline & \multicolumn{2}{|c|}{ Volume } & \multicolumn{2}{|c|}{ AWT } & \multicolumn{2}{|c|}{$\begin{array}{c}\text { AP } \\
\text { Diameter }\end{array}$} & \multicolumn{2}{|c|}{ Height } & \multicolumn{2}{|c|}{ Width } \\
\hline & right & left & right & left & right & left & right & Left & right & left \\
\hline Male & & & & & & & & & & \\
\hline Mean & 17.19 & 17.09 & 0.15 & 0.16 & 3.5 & 3.51 & 3.5 & 3.49 & 2.76 & 2.75 \\
\hline SD & 4 & 3.89 & 0.03 & 0.04 & 0.31 & 0.31 & 0.3 & 0.32 & 0.32 & 0.26 \\
\hline Median & 14 & 15 & 0.15 & 0.15 & 3.4 & 3.4 & 3.57 & 3.5 & 2.69 & 2.7 \\
\hline Range & $\begin{array}{l}10.5- \\
29.6\end{array}$ & $10.5-29.6$ & $0.09-0.27$ & $0.1-0.33$ & $3-4.3$ & $3-4.5$ & $2.9-4.1$ & $\begin{array}{l}2.8- \\
4.2\end{array}$ & $\begin{array}{l}2.2- \\
3.8\end{array}$ & $\begin{array}{l}2.3- \\
3.3\end{array}$ \\
\hline Female & & & & & & & & & & \\
\hline Mean & 15.21 & 15.64 & 0.14 & 0.13 & 3.39 & 3.39 & 3.33 & 3.34 & 2.66 & 2.71 \\
\hline SD & 3.2 & 3.5 & 0.02 & 0.02 & 0.25 & 0.29 & 0.22 & 0.21 & 0.31 & 0.32 \\
\hline Median & 16 & 16 & 0.14 & 0.13 & 3.5 & 3.6 & 3.3 & 3.4 & 2.61 & 2.65 \\
\hline Range & $\begin{array}{l}10.4- \\
24.8 \\
\end{array}$ & $10.5-24.6$ & $0.11-0.1$ & $0.11-0.1$ & $2.9-3.85$ & $\begin{array}{l}2.9- \\
3.82\end{array}$ & $2.8-3.8$ & $\begin{array}{c}2.88- \\
3.7\end{array}$ & $\begin{array}{l}2.2- \\
3.6\end{array}$ & $\begin{array}{l}2.1- \\
3.7\end{array}$ \\
\hline
\end{tabular}

Table 2: P-Value of Volume of maxillary sinus (One Way ANOVA)

\begin{tabular}{|l|l|}
\hline Volume & P-Value \\
\hline Left and Right side of female & 0.54 \\
\hline Left and Right side of male & 0.89 \\
\hline $\begin{array}{l}\text { Left side of both Male and } \\
\text { Female }\end{array}$ & 0.012 \\
\hline $\begin{array}{l}\text { Right side of both Male and } \\
\text { Female }\end{array}$ & 0.012 \\
\hline
\end{tabular}

\section{DISCUSSION}

The aims of this study were to estimate different dimensions of the maxillary measured on CT PNS, define a cut-off values for the normal upper and lower limits of the different measured structures. Four dimensions of maxillary sinus were measured (i.e. AP diameter, AWT, Cranio-caudal diameter, Width).

And by comparing the mean volume of both sides between male and female, a significant difference between male and female was shown with p-value 0.012 at $95 \% \mathrm{CI}$. However, the comparison of volume between left and right side of both genders didn't show significant difference. Similarly, the thickness of anterior wall measured at canine fossa was larger in male than female.

This result agreed with the result of the study conducted by Sahlstrand-Johnson et $\mathrm{al}^{1}$, Sharma et $\mathrm{al}^{4}$ and Dkhar $\mathrm{W}$ et $\mathrm{al}{ }^{5}$ whose results was larger dimensions of maxillary sinus in males than female. The mean value of the maxillary sinus volume was $15.7 \pm 5.3 \mathrm{~cm}^{3}$ (p $=0.04) .{ }^{1}$ The average volume in female was $13.92 \mathrm{~cm}^{3}(\mathrm{SD}=4.29)$ and male was 15.031 $\mathrm{cm}^{3}(\mathrm{SD}=5.15)$. In this study, the mean volume of male in left and right side were $17.09 \mathrm{~cm}^{3}, 17.19 \mathrm{~cm}^{3}$ respectively whereas in female were $15.64 \mathrm{~cm}^{3}$ and $15.21 \mathrm{~cm}^{3}$ respectively as shown in Table 1 . This shows the volume of male was significantly larger than female with P- Value $=0.012(<0.05)$. This shows the result of the maxillary sinus measurements is consistent with the previous report.

Similarly, the thickness of AW of maxillary sinus was also measured in this study and the mean value of left and right side was $0.15 \mathrm{~cm}$ and $0.14 \mathrm{~cm}$ respectively. The measurement of AWT can be very useful for the decision making in surgical intervention 


\section{CONCLUSION}

This study showed that CT is a reliable method for the measurement of different dimensions of the maxillary. The result showed greater mean value of volume in male than female with significant gender wise differences. So, this study concluded that the measurement of volume of maxillary sinus can help in the identification of gender which can be very useful for forensic sciences. This type of study should be done in larger number of normal adult population to make the study more reliable.

\section{CONFLICT OF INTEREST}

None

\section{SOURCES OF FUNDING}

None

\section{REFERENCES}

1. Sahlstrand-Johnson P, Jannert M, Strömbeck A, Abul-Kasim K. Computed tomography measurements of different dimensionsofmaxillaryand frontal sinuses. BMC Medical Imaging 2011;11(1):8 https://doi.org/10.1186/1471-2342-11-8

2. KanthemR, Guttikonda V,Yeluri S, Kumari G. Sex determination using maxillary sinus. J Forensic Dent Sci 2015;7(2):163-167 $\mathrm{h} \mathrm{t} \mathrm{t} \mathrm{p} \mathrm{s}: / / \mathrm{d} \mathrm{x} . \mathrm{d} \mathrm{o}$ i. org/10.4103\%2F0975-1475.154595
3. Sidhu R, Chandra S, Devi P, Taneja N, Sah K, Kaur N. Forensic importance of maxillary sinus in gender determination: A morphometric analysis from Western Uttar Pradesh, India. Eur J Gen Dent 2014;3(1):53-56 Available from: http://www.ejgd.org/text. asp?2014/3/1/53/126213 [Accessed 20th Dec 2018].

4. Sharma SK, Jehan M, Kumar A. Measurements of maxillary sinus volume and dimensions by computed tomography scan for gender determination. Journal of the Anatomical Society of India 2014; 63(1):36-42. https://doi.org/10.1016/j.jasi.2014.04.007

5. Dkhar W, Pradhan A, Shajan M. Measurement of Different Dimension of Maxillary and Frontal Sinus Through Computed Tomography. Online $J$ Health Allied Scs 2017;16(1):5. https://www.ojhas.org/issue61/2017-1-5. pdf 